\title{
Book Six: Dissolution
}

\section{The decline of virtue in the age of Kali}

\section{Maitreya:}

You've described in detail the creation of the world, great sage, the lineages of patriarchs, the duration of the Manvantaras and the deeds of the dynasties. 1

Now I wish to hear about the destruction of the world, known as the 'great dissolution', and annihilation at the end of every era, foremost sage. 2

\section{Parāśara:}

I'll now describe precisely how dissolution happens at the era's end, Maitreya, and explain how primal nature is absorbed. 3

One day and night for ancestors are a month for mortals. One year for mortals is a day and night for gods. Two sets of a thousand cycles of four ages are a day and night for Brahmā, best of brahmins. 4

Kṛta, Tretā, Dvāpara and Kali are the ages, and each fourfold cycle takes twelve thousand years of gods. 5

Every cycle is the same, Maitreya, as they start with Krtta and end with Kali. 6 In the beginning, Brahmā creates the world in the Kṛta age, and he brings about its dissolution in the age of Kali. 7

\section{Maitreya:}

Please describe in detail the nature of this age of Kali, master, during which fourfold virtue is corrupted. 8 


\section{Parāśara:}

You want to ask about the nature of the Kali age, Maitreya, so listen, sage, because that age is now upon us. 9

At this time, folk no longer follow the provisions for their orders or stage of life, nor do they perform the rites determined by the Säma, $R g$ and Yajur Vedas. 10

Marriage in the Kali age is no longer moral, nor do students live in their gurus' homes. The customs governing husbands and their wives will be ignored, as will rituals for the sacred fires and deities. 11

In this age, a powerful lord, irrespective of his natal clan, will feel entitled to procure a woman of any order. 12

In the age of Kali, a twice-born man may be initiated into any spiritual tradition, but, irrespective of his choice, Maitreya, it will merely be atonement. 13

Anything said to be a scripture will be thus regarded in the Kali age, brahmin; anything may be worshipped as a god and anyone may follow each stage of life. 14

Fasting, austerities and donations made by those who feel the need will amount to virtue at this time. 15

Pride in small amounts of wealth will count as riches in the age of Kali, and women will be proud of their appearance, merely thinking of their hair. 16 In the Kali age, when garments have no gold or gems, jewels or other ornaments, women's only source of beauty will be coiffure. 17

Wives will abandon husbands when they lose their wealth, but will marry any man with money in this age. 18

One who pays the biggest bribes gains mastery over men, and positions of nobility will derive from one's connections, not one's birth. 19

One's concerns will be limited to one's home, one's wealth and chattels, and money will be squandered on amusements in the age of Kali. 20

Women will be free and yoked to pleasure, while men will hanker after ill-gotten gains. 21 
Even when requested by a friend, a person will not give up one-eighth part of a farthing, brahmin. ${ }^{1} 22$

Commoners regard themselves as equal to the brahmins in this age, and cows are only valued for their milk. 23

All will live in fear of drought - the cause of famine-always looking at the sky. 24

Wracked by drought and other troubles, they will starve themselves to death, eating roots and leaves and berries like ascetics. 25

Always hungry, troubled and unprotected, they'll find no ease or pleasure in the age of Kali. 26

They'll eat before they wash; sacred fires and gods and guests will not be tended; nor will they offer water to the ancestors when this age arrives. 27

Women will be greedy, short and gluttonous, having few resources but many mouths to feed. 28

Scratching their heads with both their hands, surly women will ignore the orders of their elders and their husbands. 29

They'll be selfish, sullen, slovenly, abusive and untruthful in the Kali age. 30 Even well-born women, drawn to wicked men, will be vulgar and depraved. 31

Boys and the uninitiated will receive instruction in the Vedas, and householders will neither sacrifice nor make suitable donations. 32

Ascetics in the forests will take the food of villagers, and mendicants will be bound by bonds of sentiment to family and friends. 33

Kings will not protect their subjects, but, under the pretext of levying taxes, will plunder them like bandits when the age of Kali comes. 34

Anyone rich in horses, chariots and elephants will be a monarch, and the weak will be their subjects at this time. 35

Vaiśyas will leave their natural occupations in trade and farming and will take on roles of śūdras and live as artisans. 36

The lowliest suuddras will take the vows of mendicants and, bearing outward signs of wandering monkhood, will lead a life of heresy, being unordained. 37

1 Pana, or farthing, is the copper coin of least value. 
Miserable people, gravely oppressed by the weight of tax and famine, will flee to lands still rich in wheat and barley. 38

When the Vedic path has been abandoned and folk devote themselves to heresy, with the spread of vice, the people's lifespan will decrease. 39

Folk will practise awesome penance not sanctioned by the scriptures, and infants will perish on account of the sovereign's sins. 40

Girls will bear children at the age of five or six or seven with boys aged eight or nine or ten in the Kali age. 41

The hair of youths will turn grey at twelve, and none will live past twenty. 42 Since men are foolish, false and mean, they'll all die young in the age of Kali. 43

Whenever a rise in heresy is noted, Maitreya, the wise infer the spread of Kali. 44

Whenever pious men on the Vedic path grow fewer, the wise perceive the growth of Kali. 45

When the endeavours of men who practise virtue vanish, then the rise of the age of Kali is inferred by the learned. 46

When the lord of sacrifice, foremost being, is no longer honoured by men with offerings, the influence of this age can be discerned. 47

When people find no joy in Vedic recitation but delight in heresy, best of brahmins, the wise infer the spread of Kali. 48

During this period, Maitreya, people are seduced by heresies and no longer worship Viṣnu, the universal lord, the master and creator of the world. 49

Brahmin, those seduced by heresies exclaim, 'What do we care for gods or brahmins, the Vedas or ritual baths!' 50

Parjanya will release few showers, brahmin, the crops will yield but little grain and fruit will have no substance when the Kali age begins. 51

Most clothes will be made of flax, most trees will be samis and the people mostly śüdras. 52

Most grain will be millet, most milk will come from goats when the age of Kali comes and massage oil will be made from usíra-grass. 53 
One's in-laws will be honoured in preference to one's parents in the age of Kali, best of sages. One will befriend the brothers of one's wife, her kin and men with pretty wives. 54

'What's a mother and what's a father, when one's role is shown by actions?' Such will be the view of those who regard their parents-in-law as their own. 55 Constantly beset by sins of body, voice and mind, foolish folk will err each day. 56

All that causes pain to false, impure and shameless men will flourish in the age of Kali. 57

When Vedic recitation ceases and the cries of vasat, svadhā and svāha are heard no more, the world will be as if alone. 58

In that world, one may, with little effort, earn a peerless store of merit, which, in the Kṛta age, would require much more austerity. 59

So ends Chapter One in Book Six of the glorious Viṣnn Purāna.

\section{Vyāsa reveals the single virtue of the Kali age}

\section{Parāśara:}

Hear me, fortunate sage, while I truthfully relate wise Vyāsa's words in this regard. 1

There was once a debate among the seers about the age in which the smallest virtue gave the most reward, and by whom this could be achieved most easily. 2

To put forward their uncertainties and dispel their doubts, the leading sages called on Vyāsa, the greatest seer and arranger of the Vedas. 3

They saw my son, the blessed sage Veda-vyāsa, in the waters of the Gangā, brahmin, performing his ablutions. 4

Those great seers waited on the bank of that mighty river in a shady grove while Vyāsa finished washing. 5

Rising from the waters of the river where he'd been bathing, my son Vyāsa cried, 'This age of Kali is the best! The very best!' Those sages heard his cry as he dived back underwater. $\sigma$ 
When he emerged a second time, he shouted, 'Śūdra, you're the best. The very best! How fortunate you are!' 7

Once more the sage immersed himself and, coming up again, he cried, 'Women are the best and luckiest. Who's luckier than them?' 8

When my son had finished washing, duly rinsed his mouth and completed all the rites, those holy seers approached him with respect. 9

They offered salutations and found themselves a seat. Vyāsa, son of Satyavatī, then asked them why they'd come. 10

'We came to ask about some doubts,' they said, 'but let's forget all that. Now we want you to explain another matter. 11

You just said the Kali age, a śūdra and a woman are the best, and stated that they're fortunate. 12

We want to hear about this, sage, as long as it's not secret. Then we'll ask about the other thing that's on our mind.' 13

Thus questioned by the sages, Vyāsa gave a laugh and said, 'Listen, best of seers, to why I said that they're the best. 14

Merit that takes ten years to earn in the Krta age takes but a single year in the Tretā, a month in the Dvāpara and just a day in this age of Kali. 15

The same applies to the rewards of austerity, the student's life of chastity, the recitation of mantras and so on, brahmins. That's why I said the Kali age is best. 16

The rewards for meditating in the Kṛta, sacrificing in the Tretā and worshipping in the Dvāpara may all be won by merely adoring Keśava in the age of Kali. 17

A person may experience a great increase in his merit with little effort in this age. That's why I delight in it, you sages who know virtue. 18

The Vedas are adopted by the twice-born orders who've taken vows. They then perform the sacrifice with wealth acquired through communal duty as ordained by custom. 19

Recitation, sacrificial feasts and offerings don't benefit those communities, and are always undertaken by self-restrained practitioners to their detriment. $^{2} 20$

2 This is a strange statement as it stands. The commentator explains that this is the case if the practices do not include the worship of Kṛ̣ṇa-Viṣnu. 
If these rites are not performed correctly, the doers incur iniquity from them all. Merely eating and drinking, brahmins, will not confer the outcome they desire. 21

In all their undertakings, they're subject to the will of others, brahmins, and attain the realms ordained for them with difficulty. 22

By serving the twice-born orders, a śūdra who oversees the offerings of food attains the realms ordained for him and is therefore luckier. 23

Since there's no restriction for such a person on what he may or may not eat or drink, you tigers among sages, I say that he's the best. ${ }^{3} 24$

The wealth that's won by men through constant obedience to communal duty should be placed in worthy hands or spent on sacrifice, as prescribed by custom. 25

Great pains are undergone in earning and retaining wealth, you best of brahmins, and similarly, men know pain from its improper use. 26

Enduring these and other challenges, men attain their proper realms, best of brahmins, such as that of Prajāpati and others, in order of their merit. 27 A woman may attain the same realm as her husband, brahmins, merely by attending him with body, voice and mind. 28

She's unlike the man who only wins such realms through great travails. That's the reason for my third remark, that women are the best. 29

Now that I've explained all this to you, brahmins, feel free to ask the question that brought you here, and I'll duly answer.' 30

\section{Parāśara:}

'The matter that we came to ask about,' the sages said, 'has been addressed most adequately in your response to our second question, sage.' 31

Vyāsa Kṛ̣ṇa-Dvaipāyana the seer then laughed and addressed the gathered ascetics, whose eyes were wide with astonishment. 32

'With divine insight, I perceived your question. That's why I said, "The best, the very best!" to you in that regard. 33

Merit is achieved in the Kali age with little effort by those whose faults are washed away by the water of their own virtues: 34

3 The idea seems to be that śüdras, who are not subject to dietary restrictions, can never be faulted for breaking dietary rules. This makes it easier for them to reach the heavenly realms designated for them. 
By śüdras intent on serving the twice-born orders, best of sages, and similarly, by women with the simple task of waiting on their husbands. 35

Hence, I regard these three as fortunate, as it's fraught for twice-born folk to win such merit in the Krrta age and others. 36

I've told you all you wished to hear, even before you brahmins who know virtue asked. What further may I do for you?' 37

\section{Parāśara:}

The sages worshipped Vyāsa and praised him repeatedly, then departed as they'd come, their doubts dispelled by him. 38

I've revealed to you this secret, lucky sage, the sole great virtue of the terrifying age of Kali. 39

I'll now describe the destruction of the world you asked about, and the periodic breakdown of the elements. 40

So ends Chapter Two in Book Six of the glorious Viṣnu Purāna.

\section{The causal dissolution at the end of every aeon}

\section{Parāśara:}

It's thought that dissolution of creation is threefold: causal, elemental and final. 1

Causal or Brāhma dissolution occurs at the end of every aeon. Elemental dissolution occurs after two parärdhas, and final dissolution is liberation from existence. ${ }^{4} 2$

\section{Maitreya:}

Describe for me the duration of a parārdha, master, after two of which, elemental dissolution then occurs. 3

4 A kalpa or aeon is one of Brahmā's days and two parārdhas constitute his entire lifespan. Liberation from existence, or mokșa, is the highest goal of spiritual practice. 


\section{Parāśara:}

Counting from one place to the next in the decimal system, brahmin, a parärdha is said to occupy the eighteenth place. ${ }^{5} 4$

The dissolution that occurs after two parärdhas is elemental, brahmin. At that time, the Seen is absorbed into the Unseen, which is its ultimate cause. 5

A nimesa-a blinking of the eye-is the length of a short syllable in the Sanskrit language. Fifteen nimesas make one kāsțthā, and thirty kāssthās make a kalā. ${ }^{6} 6$

\section{A nā dikā lasts for fifteen kalās. 7}

Measured with a water clock, a nădika is also the time taken to fill a vessel made of twelve and a half palas of copper, having the capacity of one prastha of water (following the Magadhan system of measurement), with a hole in the bottom into which is inserted a tube made of four māsas of gold, as long as four fingers are wide. ${ }^{7} 8$

Two nādikās make one mubürta, best of brahmins. There are thirty mubürtas in one day and night, and thirty days in a month. 9

There are twelve months in a year, which is one day and night for gods. Three hundred and sixty mortal years are one year for gods, the rivals of the demigods. 10

One cycle of four ages takes twelve thousand divine years, and a thousand such cycles are said to be a day for Brahmā. 11

One such day is one aeon or kalpa, during which fourteen Manus preside, great sage. At the end of each aeon, the causal or Brāhma dissolution of the world takes place, Maitreya. 12

The nature of elemental dissolution is terrifying, Maitreya; now listen while I describe it for you. 13

\footnotetext{
5 That is, $10^{18}$ or one million million million years.

6 The verses on units of time are virtually a repeat of verses $1.3 .8 \mathrm{ff}$.

7 The root text is incomprehensible. My rendering-more an attempt at explanation than a translation-is a synthesis of a number of sources, including the two very lengthy Sanskrit commentaries and the prior attempts by my two brother translators and their respective footnotes. It seems that an empty vessel of known weight and volume with a tube of known weight and length inserted into its base is set in a larger container of water. The time taken for such a vessel to fill and sink is one nädikā. See also Fleet (1915).
} 
At the end of a thousand cycles, when the earth is generally exhausted, there'll be a dreadful drought that lasts a hundred years. 14

As a result, all living things on earth, lacking nourishment, proceed to their destruction, best of sages, driven by their suffering. 15

Next, Krṣna, the eternal lord, appearing in the form of Rudra, will strive for the dissolution of all beings that abide within himself. 16

Lord Viṣnu, occupying seven solar rays, then imbibes the waters, best of sages. 17

By absorbing all the moisture from the earth and living things, Maitreya, he desiccates the world. 18

He'll destroy the oceans and the rivers, the mountains and their streams and the water found in Pātāla and other lower realms. 19

Next, with his power, those seven rays, strengthened by the added water, give rise to seven suns. 20

Blazing up and down, brahmin, those suns will burn the threefold worlds and all the lower realms. 21

The threefold worlds, with mountains, seas and rivers, brahmin, being scorched by those blazing suns, will lose their moisture. 22

When all the world is robbed of plants and water, brahmin, it resembles a tortoise shell. 23

All-consuming Hari, appearing in the form of Rudra and the conflagration at the end of time, then becomes the serpent Seșa's scorching breath and burns the lower realms of Pātāla. 24

When that blaze has burned those realms, it spreads up here and destroys all things upon the surface of the earth. 25

A great, cruel whirling wreath of flames consumes the world, the atmospheric realms and heavens. 26

All threefold worlds then glow like a griddle, ringed by swirling flames, deprived of lifeforms, mobile and immobile. 27

Beset by heat, the residents of the upper realms, great sage, who are privileged to do so, then retreat to Maharloka. 28

But when that realm becomes too hot for them, its denizens, fleeing for their lives and seeking somewhere higher, withdraw to Janaloka. 29 
When Janārdana in Rudra's form has burned the world, best of sages, the breath emerging from his mouth gives rise to clouds. 30

These terrifying clouds, called Samvartakas, resembling herds of elephants, shedding bolts of lightning and roaring thunderously, arise above. 31

Some are blue like utpala lilies, some glow white like kumuda flowers, some are grey as smoke and others yellow. 32

Some are dun like donkeys, some are red as lodh-tree sap, some are blue as lazuli, others are green as emerald. 33

Some are white as conch or jasmine flowers, some are black as kohl, some glow like fireflies and others are as red as arsenic. 34

Some arise like mounds the hue of blue-jay feathers, some resemble splendid cities, others tower like mountains. 35

Some rise up like roof-top dwellings, while others appear flat. Huge and rumbling, they fill the sky. 36

Shedding mighty torrents, brahmin, they quell the dreadful fires that swept across the threefold worlds. 37

They douse the flames, then pour down rain for a hundred years or more, best of sages, inundating this whole world. 38

When all the earth is filled with raindrops as big as dice, the waters flood the atmospheric realm and then the heavens, brahmin. 39

And when this whole dark universe with all things moving and unmoving has disappeared, those great clouds rain for yet another century. 40

So ends Chapter Three in Book Six of the glorious Viṣnu Purāna.

\section{The elemental dissolution}

\section{Parāsara:}

When they reach the dwelling of the Seven Sages, the waters cease to rise, great seer, and all this threefold universe becomes a single ocean. 1

Wind born as breath from Viṣnu's mouth dispels the clouds, Maitreya, and blows for yet another hundred years. 2

The lord, who is all things, beyond all thought, creation's source, beginningless yet the origin of all, then absorbs the wind in its entirety. 3 
In the middle of that ocean, Lord Viṣnu rests on Śeșa as on a couch, then Hari, source of all, in Brahmā's form, reposes. 4

Adored by Sanaka and other siddhas who withdrew to Janaloka, and contemplated by those who rose to Brahmaloka seeking liberation, 5

Firm in heavenly yoganidrā, which emanates from his own illusion, the highest lord contemplates himself in the form called Vāsudeva. 6

This is known as causal dissolution, Maitreya, because it's caused by Hari reposing in the form of Brahmā. 7

When that universal being awakes, the world begins to stir and, when the everlasting god reclines upon his own bed of illusion, the whole world shuts its eyes. 8

Just as one day for lotus-born Brahmā is a thousand cycles of ages, the night, when the world is submerged beneath the universal ocean, is of the same duration. 9

When he wakes at the end of the night, Viṣnu, the unborn being in the form of Brahmā, creates the world again, as I explained to you before. 10

I've thus described the causal dissolution at the end of every aeon, brahmin. Now listen while I describe the elemental dissolution. 11

After the onslaught of drought and fire, sage, when everything in all the worlds and the lower realms of Pātāla is under water, 12

The elemental dissolution starts, in which the permutations of mabat and all the other basic elements are destroyed in accordance with the will of Kṛ̣na. 13

The waters swallow up the quality previously possessed by earth, the phenomenon of scent, and, when the element of earth is robbed of scent, it is destroyed. 14

The earth without its fragrance is united with the waters. The rushing, roaring waters then increase. 15

Filling all the world, the billowing floods spread fitfully across each realm on every side. 16

The quality of taste imbuing water is then absorbed by the element of fire and, when that quality is lost, water is no more. 17

When the waters lose their taste, they become one with fire and, when this happens, fire overtakes the world. 18 
When fire spreads in all directions, it consumes the waters, and this whole world is slowly filled with flames. 19

When the universe above, below and on all sides is burned by fire, the element of air then swallows form, the ultimate quality of fire. 20

When fire has been entirely reduced to air and the element of form destroyed, then light is deprived of form. 21

Light grows dim and the element of air begins to tremble when the world is dark, and fire and air are one. 22

Air, having reached the root that is its origin, shakes violently in all directions: above, below and on each side. 23

Space then swallows touch, the property of air. Air grows still, and limitless space alone abides. 24

Lacking form, taste, touch, scent and shape, space appears in pure immensity and fills the universe. 25

Vacant and ubiquitous, it's characterised by the quality of sound. Consisting of sound alone, space is all-pervading. 26

When the elements with sound and other qualities have been absorbed together, they're characterised by pride and dullness, it is thought. 27

The elements and all the rest are swallowed by mabat, the element of Greatness, which is characterised by intellect. 28

The earth and mabat form the inner and outer limits of the universe. 29

Thus, the seven natural elements that arise from mahābuddhi, 'great intellect', all re-enter one another at the time of elemental dissolution. 30

The cosmic egg is dissolved in the waters that surround it, along with the seven continents and oceans, the realms and mountain ranges. 31

This sheath of water is then absorbed by fire; fire by air, and air by space. 32 Mahat and other elements swallow space and the elemental state, prakrti, absorbs mahat, along with all the elements, brahmin. 33

When the qualities are in balance, neither too little nor too much, sage, it's called the elemental state, prakrti, the origin, primal Nature, the highest cause. 34

Thus, this entire elemental state is both Seen and Unseen, and the first is absorbed into the second, Maitreya. 35 
The singular, pure, immutable, eternal, ubiquitous primal Spirit, pums, is also an aspect of the universal highest Self, Maitreya. 36

Concepts such as name and station don't apply to the universal lord, who should be understood as pure existence and who consists in knowledge and transcends the Self. 37

This is brabman. This is the Absolute. This is the abode, the highest Self, the lord. This whole world is Viṣnu, from whom the perfect sage does not return. 38

Primal Nature, prakrti, which I've described, manifest and unmanifest in form, and primal Spirit, purusa, are absorbed by the highest Self. 39

This highest Self, foundation of the universe and highest lord, is hymned by name as Viṣnu in the Vedas and their supplements. 40

Sacrifice and renunciation are two forms of pious acts prescribed in Vedic texts. Through these two paths, men worship Viṣnu in universal form. 41

Following the paths of the $R g$, Yajur and Sama Vedas, the lord and spirit of the sacrifice, the highest spirit, is adored by men with sacrifices. 42

Viṣnu, who confers rewards of liberation and is at the heart of knowledge, is worshipped in the form of knowledge through the yoga of knowledge by ascetics on the path of renunciation. 43

All that's named with short, long or extended syllables, and all that's beyond the reach of words, is eternal Viṣnu. ${ }^{8} 44$

He is Seen, Unseen, eternal Spirit, highest Self, universal Self and Hari of universal form. 45

Primal Nature, consisting of the Seen and Unseen, and primal Spirit, Maitreya, are absorbed into that all-pervasive, unimpeded state. 46

The period of two parârdhas that I described to you, Maitreya, is said to be a single day for Viṣnu. 47

When the Seen is absorbed into primal Nature, and Nature is absorbed in Spirit, and Spirit is absorbed in that supreme being, then there is another period, a night, which is of the same duration as one of Viṣnu's days, great sage. 48

8 Syllables in Sanskrit are short, long or, very rarely, 'prolated', and are held for one, two or three beats, respectively. 
There is, in fact, no day or night for the everlasting highest being, brahmin. It's just a way of speaking of the lord. 49

Thus, I've described the dissolution of the elements for you, Maitreya. Now you'll hear about the final dissolution, brahmin. 50

So ends Chapter Four in Book Six of the glorious Viṣnu Purāna.

\section{The final dissolution and the nature of suffering}

\section{Parāśara:}

The wise person who understands three kinds of worldly suffering, including pain arising from within, Maitreya, and in whom spiritual knowledge and dispassion have arisen, will attain the final dissolution. 1

Pain arising internally is of two kinds, affecting both the body and the mind. Bodily afflictions are divided into many classes. Listen to these: 2

Headaches, colds, fever, gout, fistula, spleen, haemorrhoids, asthma, tumours, vomiting and many others. 3

There are also diseases of the eye, dysentery and leprosy. This is how bodily afflictions are classified. Now hear about afflictions of the mind. 4

Desire, anger, fear, hatred, greed, delusion, depression, grief, envy, contempt, jealousy, selfishness and other emotions -5

There are many such mental afflictions, best of brahmins. These are the classes of suffering arising from within. 6

Wild animals, birds and other people, flesh-eating piśāca demons, serpents and rākșasas, as well as snakes and insects-these living things may bring harm to people. 7

I shall also mention suffering inflicted by natural forces, including cold, heat, wind, rain, floods and lightning, most excellent of brahmins. 8

The sufferings arising in pregnancy, birth, old age, ignorance, death and hell are divided into myriad classes, best of sages. 9

The tender-bodied embryo in the womb is surrounded by filth, wrapped in a caul, with its back, neck and bones hunched over. 10 
The suffering of the growing foetus is heightened by discomfort caused by acidic, pungent, sharp, hot and salty foods eaten by its mother. 11

Unable to stretch or bend its limbs and lying in a mire of excrement and urine, it's afflicted on all sides. 12

It cannot breathe but is conscious and, recalling earlier births by the hundred, it waits in the womb amid great suffering, bound by deeds performed in previous lives. 13

As it's being born, its face is smeared with faeces, urine, blood and semen, and its bones and sinews wracked by labour pains. 14

Upside down, it's squeezed from the womb by strong and painful contractions and is beset by woe. 15

The infant is deprived of earlier memories when it breathes the air outside, best of brahmins, and is born in ignorance. 16

As if its limbs are pricked by thorns or hacked with saws, it falls to the ground like a maggot from a foetid wound. 17

Unable even to scratch itself, the infant lies in a helpless state, dependent on the will of others for washing, food and drink. 18

Lying on a dirty rug, the babe is bitten by mosquitoes, bugs and other pests, and cannot fend them off. 19

Many are the earthly pains attending birth, and many are those which follow them in childhood. 20

Shrouded in ignorance and dullness, and filled with delusion, the individual knows not whence he came, who he is, whither he will go or his own nature. 21

He knows not the bonds that bind him, what's a cause and what is not, what's to be done and what is not, what's to be said and what is not, 22

What is virtue and what is not, where virtue exists and why, what is duty and what is not and what is good and what is not. 23

Thus, deluded individuals, obsessed with their own penis and their stomach, are no better than the animals and endure great suffering born of ignorance. 24

Ignorance is a state of dullness, brahmin, because of which unknowing beings, who should engage in sacrifice, neglect such acts. 25 
Great sages have declared that hell is the consequence of neglected worship. As a result, the ignorant suffer greatly in this life and the next. 26

When a man's body is old and frail, his limbs grow weak, his teeth are loose or missing and sinews, veins and wrinkles cover him, 27

He can't see far but stares blankly, hairs sprout from his nostrils and he's wracked by tremors. 28

His bones stick out, his back is bent, his joints are swollen, he eats little as digestion fails and he hardly moves at all. 29

It's hard for him to walk or rise, lie or sit or move; his eyes and ears grow weak; he dribbles down his chin. 30

All his senses fail as he approaches death, and he forgets events as soon as they have happened. 31

When he has to repeat himself, he's overcome with weariness, but the dreadful strain of drawing breath and coughing robs him of his sleep. 32

When a man is old, others must help him up, and others dress him, but his servants, sons and wife all mock him. 33

He cannot clean himself, yet still craves food and other pleasures. His attendants laugh at him and all his kin ignore him. 34

Recalling exploits of his younger days as if they happened in another lifetime, he sighs deeply and is troubled. 35

Having endured the woes of dotage, now hear about the torments met in death. 36

His neck, fingers and hands hang loose and his body begins to twitch. One minute, he lies limp and tired, the next, he seems to wake a little. 37

Remembering the things he owns, he frets about his gold, stores, sons, wives, servants, houses and all the rest. 38

His bones and joints are wracked by stabbing pains of Death's sharp arrows, which rip his vital organs like cruel saws. 39

His eyes roll back, his hands and feet convulse, his palate, lips and tongue are dry, then the rattle of death is heard. 40

His throat is blocked by floods of morbid humours and breath is laboured. Afflicted by great suffering, thirst and hunger torment him. 41 
Overwhelmed by pain as Yama's minions goad him, he dies, only then to receive another body to be tortured in the realms of hell. 42

The living endure these and other frightful pains at the time of death. Now listen to the torments that the dead will meet there. 43

Caught in the noose of Yama's servants and struck with rods, they must bear the fearful sight of the Lord of Death as they face the terrible road to hell. 44

In that realm of frightful burning sands, fires, machines, weapons and the rest are found each kind of hellish torment, brahmin, so difficult to endure. 45 Hacked with saws, cooked in pots, chopped with axes, buried in the ground, 46

Impaled on stakes, eaten by tigers, torn by vultures, devoured by leopards, 47 Boiled in oil, drowned in slime, dropped from heights, thrown from catapults- 48

The torments they endure in hell, arising from their own misdeeds and administered by the denizens of that realm, brahmin, are innumerable. 49

But hell is not the only place of pain, best of brahmins. In heaven, too, a being is never free from the fear of falling to a lower realm. 50

There he will be conceived, only to be born once more. Leaving the womb and entering the world again, he's destined for another death. 51

He may die an infant or in childhood, as a youth or adult or in his dotage, but death is certain. 52

While he lives, he's beset by varied troubles, like a cotton seed amid a mass of fibres before they're spun as thread. 53

Winning, keeping and losing wealth all bring woe to men, as do the pains of those we love. 54

Each thing that brings us joy, Maitreya, becomes the seed of a tree of pain. 55

Wives, sons, friends, possessions, houses, fields, wealth and all the rest cause more trouble than the joy they yield. 56 


\section{Vāsudeva as the antidote to suffering}

Where may those whose hearts are thus tormented by scorching rays of worldly pain seek shelter, other than the shade of the tree of liberation? 57

The wise therefore hold that the antidote for this threefold suffering arising in the womb-birth, old age and the other states of life -58

Is complete and final union with the lord, which alone is marked by a state of bliss and eclipses every other joy. 59

That's why the wise should strive for him. Knowledge and sacrifice are said to be the means for doing so, great sage. 60

They say that knowledge is twofold, arising from scripture and from reflection. Scripture consists of the Absolute in the form of the Word, but the highest form of the Absolute is born of meditation. 61

Just as the sun dispels the deepest darkness, wise brahmin, so, too, does knowledge gained through the senses and born of meditation shine like a lamp on ignorance. 62

Manu himself relayed the import of the Vedas as he recalled it, best of sages. Now listen as I repeat what he said in this regard. 63

Two forms of the Absolute are to be recognised: the Word and the Supreme. One well versed in the former may reach the highest state of the latter. 64

The Atharva Veda also describes two forms of knowledge. By means of the higher, one attains the imperishable state, while the other consists of the $R g$ and other Vedas. 65

That which is unmanifest, unageing, inconceivable, unborn, undecaying, indescribable, formless, lacking hands and feet and other features 66

Is the universal, eternal lord, the uncaused source of all creation, the allpervading but unpervaded origin of everything-it's this the sages see. 67

This is the Absolute, Supreme, the abode to be contemplated by those who yearn for liberation. Subtle, but alluded to by words of sacred scripture, it's the highest state of Viṣnu. 68

The word 'blessed'-bhagavant-is also a form of the Supreme, and is the means of expressing the primal, eternal being. ${ }^{9} 69$

9 The word bhagavat literally means 'possessing fortune'. It is a common epithet used for ViṣnuKṛnna in the Vișnu Purāna and for other major deities and sages. I have consistently but reluctantly translated it as 'lord' or occasionally as 'blessed'. The following verses only become intelligible if this word is left untranslated. 
One who truly grasps the import of this expression will comprehend the other form of knowledge embodied in the Vedas. 70

The term bhagavat is used to worship that form of the Absolute, brahmin, which lies beyond the reach of words. 71

Therefore, Maitreya, it's used to express the pure, supreme Absolute, known as the almighty, the cause of the cause of everything. 72

The syllable bha implies the two meanings of maintainer (sambhartr) and protector (bhartr), sage, while the syllable ga signifies the leader, driver (gamayitr) and creator. 73

The syllables bba and ga express six qualities: supremacy over all, power, glory, majesty, knowledge and asceticism. 74

$\mathrm{Va}$ implies all creatures dwell (vasanti) in the universal being at the heart of all creation, and that the everlasting deity dwells in all. 75

Thus, this great word bhagavat applies to the highest Absolute, Vāsudeva and nothing else, you peerless sage. 76

In this context, the term implies a state of reverence. It has a special expressive function and is not figurative, but in other contexts, it may be so. 77

One who understands the beginning of creation and its end, the right way and its opposite and knowledge and its absence may be called a bhagavat, a blessed one. 78

In the former instance, the term denotes wisdom, energy, strength, supremacy, power and brilliance without remainder, and the absence of any negative traits. 79

As all beings dwell in the highest being and the universal being dwells in them, he is known as Vāsudeva. 80

This is how in former times Keśidhvaja, when asked about eternal Vāsudeva's name, accurately explained it to Khāṇ̣ikya Janaka: 81

Because he abides in beings and they abide in him, the creator and disposer of the worlds is Lord Vāsudeva. 82

He transcends the nature of all creation, sage, its transformations and all its qualities, good and bad. He's beyond all limits and is at the heart of everything. All space in the world is filled by him. 83 
$\mathrm{He}$ is at the heart of all blessings and goodness, and accomplishes the creation of all beings with a mere fraction of his ability. He assumes an expansive form at will, and showers benefits on all the world. 84

$\mathrm{He}$ is the sole store of energy, power, supremacy, perception, might, strength and other qualities. Higher than the highest, no faults exist in the all-inclusive lord. 85

He is sovereign, one but many, unmanifest yet visible, lord of all, all-seeing, all-knowing, all-powerful and is called the highest master. 86

That by which he's known, beheld or understood is faultless, pure, supreme, unsullied, uniform spiritual knowledge. All else is ignorance. 87

So ends Chapter Five in Book Six of the glorious Viṣnu Purāna.

\section{Khāṇ̣ikya and his cousin Keśidhvaja}

\section{Parāsáara:}

The highest spirit may be perceived through Vedic recitation and through yoga. That's why the Absolute, the means of attaining that state, is described by the formula 'It is this-tad etat'. 1

After recitation, one should practise yoga, and, after yoga, recitation. Through excellence in both, the highest spirit manifests. 2

Vedic recitation is one eye with which to see the lord, and yoga is the other, as the Absolute lies beyond the bodily eye. 3

\section{Maitreya:}

Speak on yoga, master, as I wish to understand it. When I comprehend that, I may be able to perceive the highest lord, foundation of the universe. 4

\section{Parāśara:}

I'll describe yoga to you, great sage, just as Keśidhvaja explained it to Khāṇịikya Janaka in former times. 5

\section{Maitreya:}

Who was Khāṇdikya, brahmin, and who was Keśidhvaja? How did their talk of yoga come about? 6 


\section{Parāśara:}

Janaka Dharmadhvaja had one son, Amitadhvaja, and another named Krrtadhvaja, a king who constantly found joy in the highest spirit. 7

Kṛtadhvaja had a son named Keśidhvaja, brahmin. Amitadhvaja's son was Khāṇụikya Janaka. 8

Khāṇịikya excelled on the path of ritual action and was skilled in worldly matters, but Keśidhvaja was an expert in spiritual knowledge. 9

These two, however, both wished to usurp the other, and Keśidhvaja deprived Khāṇdikya of his kingdom. 10

Driven from his realm, Khāṇikya wandered in the jungle, where travel is not easy, accompanied by his priest and ministers but taking little else. 11

He still conducted sacrifices, but, lacking true spiritual insight, he hoped in his ignorance to gain knowledge of the Absolute and escape from death thereby. 12

One day, Keśidhvaja was engaged in yoga when a fearsome tiger killed his dairy-cow in a trackless forest, you yoga expert. 13

Hearing that his cow was dead, the king then asked his priests about atonement. 14

'We don't know,' they said, 'but you should question Kaśeru.' The king then asked that sage, who gave the scion of Bhrgu the same reply: 15

'I don't know, your majesty, but ask Śunaka. He's an expert in such things.' The king then went to Sunaka and asked him, sage, and Sunaka replied, 'Listen: 16

Neither Kaśeru, nor I, nor any other man on earth at present knows the answer. The only one who truly knows is your rival Khāndikya whom you've vanquished.' 17

The king replied to Śunaka, 'I'll go and ask my enemy, sage, and even if he kills me, I'll obtain the reward of sacrifice. 18

On the other hand, if I ask him and he tells me how to make amends, then my yoga practice will be unimpaired, best of sages.' 19

\section{Parāśara:}

So saying, the king, dressed like an ascetic in a black antelope hide, mounted his chariot and entered the forest where wise Khāṇikikya camped. 20 
When Khāṇikya saw his enemy approaching, his eyes grew red with fury and, nocking an arrow to his bow, he said, 21

\section{Khäṇ̂likya:}

You attack me with a deer skin as protection, and you think I won't fight back because I'm wearing the same thing! 22

But tell me, fool, isn't this the hide from the back of an antelope that you and I both killed with our deadly sharpened arrows? 23

I'm going to kill you now. You'll not escape alive. You, the foolish thief who stole my realm, are now my enemy! 24

\section{Kesidbvaja:}

I've come to ask a question, Khāṇḍikya, not to fight you, so set aside your anger. Put down that arrow. 25

\section{Parāśara:}

Wise Khāṇdikya then consulted all his ministers and priests in private. 26

'Now your rival's in your power you should kill him,' his advisors said. 'If you do so this whole world is yours.' 27

'It's surely true,' Khāṇịkya said, 'that once he's dead the world is mine. 28

But victory in the next world will be his, even if this world belongs to me. If I forbear to kill him, I'll win in the afterlife, and he can have this mundane realm. 29

Victory in the next world is eternal, but victory here is fleeting. I'll therefore spare the man and listen to his question.' 30

\section{Parāśara:}

Khāṇdikya Janaka approached his adversary and said, 'Ask me all you wish to say, and I'll reply.' 31

Keśidhvaja told him that his cow had died, brahmin, and asked how he should make amends. 32

Khāndịkya then described to Keśidhvaja the atonement to be performed in full, brahmin, according to the law. 33

Now that great Khāṇ̣̂ikya understood Keśidhvaja’s intention, he granted him permission to proceed to the sacrificial ground, where he duly undertook the rites. 34 
When King Keśidhvaja had carried out the rituals in the proper order and according to the law, and performed the requisite purification afterwards, he'd done his duty, but then he thought, 35

'I've worshipped all the priests and honoured the assembled officiants. Similarly, I've satisfied the desires of all who wanted something. 36

I've behaved appropriately towards everybody here, so why's my heart not satisfied with this sacrifice?' 37

Reflecting thus, he realised that he hadn't paid Khāṇdikya his sacrificial fee, the guru-daksingā. 38

Mounted on his chariot, the king returned to the trackless wood, Maitreya, where Khāṇ̣ikya resided. 39

When Khāndikya saw the king returning, he raised his bow and stood intent on killing him, but Keśidhvaja spoke again: 40

'I haven't come to fight, Khāṇdikya, so don't be angry. Understand I'm here to make the payment due to you as guru. 41

I've completed all the rituals as instructed, and I wish to compensate you, so name your fee.' 42

\section{Parāśara:}

King Khāṇ ḍikya consulted with his ministers once more, saying, 'He wants to pay a fee, so how much should I ask for?' 43

'You should ask for your whole realm back again,' the ministers replied. 'Skilful men win sovereignty without deploying arms.' 44

Wise King Khāṇịikya laughed at them and said, 'Why would such a man as me request a fleeting earthly kingdom? 45

You provide advice for handling mundane matters but know nothing of the highest truth or how it may be reached.' 46

\section{Parāśara:}

Having spoken thus, Khāṇ̣ikya went to King Keśidhvaja, asking, 'Do you truly wish to pay the guru-daksina?'? 47

'Indeed, I do,' was his reply. Khāṇdikya then said, 'You're well-versed in spiritual knowledge and highest truth. 48

If you wish to pay my fee, then say what acts are able to dispel my misery?' 48 So ends Chapter Six in Book Six of the glorious Viṣnu Purāna. 


\section{Keśidhvaja instructs Khāṇḍikya in yoga}

\section{Kesidbvaja:}

Why didn't you demand my kingdom, free from impositions? Nothing is dearer to kṣatriyas than winning sovereignty. 1

\section{Khändikya:}

Understand, Keśidhvaja, why I didn't request your realm, which an unwise person might desire. 2

It's the duty of all kṣatriyas to defend their subjects and to slay in righteous battles those who challenge their authority. 3

It wasn't wrong of you to seize the kingdom from me, when I was unable to defend it. I've now set aside such ignorance that merely tied me down. 4 My desire for sovereignty was the product of my birth, my lust and greed, not the fault of another man, and was a bar to virtue. 5

Wise men think it's wrong for kṣatriyas to ask for gifts. That's why I didn't foolishly request the realm. 6

Unwise men whose hearts are carried off by a sense of self, drunk with pride, crave sovereignty—not men like me! 7

\section{Parāśara:}

King Keśidhvaja was delighted. 'Excellent!' he cried and said to Khāṇdikya Janaka with affection: 'Listen to what I say. 8

On account of ignorance, I wanted to escape from death, so I ruled the kingdom and undertook many sacrifices, but I squandered merit in enjoyments. 9

You're lucky that your heart was drawn to the power of contemplation. Now listen, pride of our family, to the nature of ignorance. 10

The error that the self consists in something that's not the self, and what is not one's own is indeed one's own, is the twofold seed from which grows the tree of ignorance. 11

The ignorant embodied being, who occupies a body composed of fivefold elements, bewildered by the darkness of delusion, stridently proclaims this view: "I am this body." 12 
The self is different from space, air, fire, water and earth, so who'd maintain that it exists within the body? 13

As the self is not an aspect of the body, what wise person thinks he owns his house, his fields and other things, when these can only be enjoyed through bodily means? 14

Similarly, as the self is not an aspect of the body, what thoughtful man regards his sons and grandsons arising from his body as his own? 15

Every act a person undertakes is to satisfy the body, but if the spirit and the body are distinct, then everything that he regards as vital will further bind him. 16

Just as a house that's built of clay is plastered with a mix of clay and water, in that same way, the body, which consists of earth, is kept alive with earth and water. ${ }^{10} 17$

If a person's body, consisting of five elements, is sustained by food of these same elements, then what has that person to be proud of? 18

Trudging on the worldly path of a thousand births, he's wearied by delusion and cloaked in the dust of yearning. 19

Washing off that dust in the warming bath of knowledge, he sheds the weariness of delusion gathered on samsāra's roads. 20

When fatigue is at an end, his heart grows light and he attains supreme nirvāna, matchless and transcending pain. 21

The self entails the pure state of nirvanna and embodies wisdom. The blemishes of suffering and ignorance mark the natural world, but not the self. 22

Water in a pot takes heat from the fire beneath it, without contact with the flames, even as it boils and bubbles, sage. 23

Similarly, the self, interacting with the natural world and corrupted by egoism and pride, manifests properties of that world, even though it's separate and unchanging. 24

That's why I say that it is the seed of ignorance and, apart from yoga, there is no antidote for suffering. ${ }^{11} 25$

10 One of the commentators suggests that 'earth' and 'water' stand for food and drink.

11 As will become apparent in the following verses, yoga in this context refers to spiritual union with the divine accomplished through meditation. 


\section{Khāndikya:}

Then describe that yoga, fortunate king. In the lineage of Nimi, you're thought to be an expert on the subject, as you grasp the sense of all the relevant treatises. 26

\section{Kesidbvaja:}

Listen, Khāndikikya, and I'll explain the reality of yoga. A sage established in this practice, having reached the state of the Absolute, will never fall from it again. 27

A man's mind is the cause of both his bondage and his liberation. Attachment to the objects of the senses causes bondage, while freedom from attachment leads to liberation. 28

Having withdrawn the mind from the objects of the senses, the knowledgeable sage should contemplate the highest lord, the Absolute, to accomplish liberation. 29

The Absolute attracts the being who shares its nature and contemplates that state, sage, just as a magnet, made of iron, has the power to attract the same material. 30

The particular mental exercise, undertaken through one's own endeavour, and during which the union with the Absolute is felt, is known as 'yoga'. 31

A practitioner whose yoga is marked by performance of the highest excellence in this regard is said to occupy the cusp of liberation. 32

A practitioner who begins to master himself in this way is said to be disciplined through yoga, and one who has attained the supreme Absolute is said to have accomplished samädhi, or perfect union. 33

If the heart of the former has been sullied by faults, then he will experience liberation after practising yoga during further lifetimes. 34

A practitioner who has accomplished samädhi will achieve liberation in his own lifetime, as his accumulated karma is soon consumed in the fire of yoga. 35

The practitioner should embrace chastity, nonviolence, truth, honesty and poverty, while remaining free from desire and directing his mind towards its proper object. 36

The self-restrained individual should undertake study, purity, contentment and austerity, while bending his mind towards the highest Absolute. 37 
These five, known as the major and minor observances, respectively, offer great rewards to those who want them, but result in liberation for those who are free from yearning. 38

Imbued with these qualities, and adopting a posture such as bhadrāsana, ${ }^{12}$ the self-restrained practitioner should discipline himself by means of the ten previously mentioned observances. 39

After repeated practice, he supresses the flow of air called pranna with breath control or prānayayma, either with a seed or without one. 40

By means of the twofold practice of alternately controlling the airflows of prāna and apana-inhalation and exhalation-a third form of control arises from the suppression of both of these. 41

The foundation for most individuals is gross form, best of brahmins, but for one who practises yoga, the foundation is the infinite deity. 42

Having withdrawn the sense organs from sensations such as sound to which they are attracted, one who knows yoga should focus on mental activities, intent on curbing senses. 43

By this practice, a state of supreme control arises even for those whose minds are fickle, but if the senses are untamed, the practitioner will remain unable to reach union. 44

With breath controlled through prānāyama, and senses curbed by the practice of withdrawal, one may set one's steadied mind on the perfect refuge. 45

\section{Khāndikya:}

Tell me, fortunate king, what's the perfect refuge for the mind, on which basis every source of blemish is destroyed? 46

\section{Kesidbvaja:}

The refuge of the mind is the Absolute, and it's twofold, sire: formed and formless, or primary and secondary. 47

Realisation of this refuge is threefold, your majesty. You must understand all this: that which is called the Absolute, that which is known as action and that which consists of both. 48

12 Authorities disagree on the definitions of this posture, but all are variations on sitting cross-legged. 
Realisation in the form of action is one; that marked by the Absolute is another; and that marked by both is the third. Hence, realisation is threefold. 49

Sanandana and other sages reached realisation of the refuge marked by the Absolute. The deities and other beings, both mobile and immobile, achieved realisation marked by action. 50

For Brahmā, born of the golden egg, and other deities, knowing their responsibilities, realisation is twofold and is marked by both Absolute and action. 51

Until all knowledge and action directed towards differentiation have ceased, for those who see distinctions, all the world is one thing and spirit is another, your majesty. 52

Realisation that is free from differentiation is pure existence, is beyond the reach of words and is to be comprehended as the Self; this is called the Absolute. 53

This is the supreme, unborn, unchanging form of formless Viṣnu, the highest spirit, marked by ubiquity and diversity. 54

Since the practitioner cannot contemplate that form, your majesty, one should meditate on the physical form of Hari that lies within the reach of all. 55

Lord Brahmā, Indra, chief of Vasus and protector of his subjects, the Maruts, Vasus, Rudras, the suns, the stars and planets, 56

Gandharvas, yakșas, Daityas and all other creatures of divine origin, humans, animals, mountains, oceans, trees and rivers, 57

All beings, your majesty, and those which are the cause of beings, beginning with primal Matter and ending with differentiated entities, sentient and insentient, 58

One-footed, two-footed, many-footed and footless-all these are manifest forms of Hari to be apprehended by three kinds of realisation. 59

All this, the entire world of mobile and immobile things, is filled with Vișnu's energy in the form of the highest Absolute. 60

This energy of Viṣnu is said to be primary. That energy which is called consciousness, ksetrajña, is secondary. That which is known as ignorance or action is called energy of the third kind. 61 
On account of the all-embracing and omnipresent energy of consciousness, your majesty, one undergoes all kinds of worldly sufferings in succession. 62 And because it's obscured by that third force, the energy known as consciousness is observed to a greater or lesser degree in creatures, sire. 63

In unliving things, it's very weak. In living things that do not move, it's a little stronger. In those that creep or slither it's stronger still, and stronger yet again in those with wings. 64

It's stronger in wild animals than in birds, and stronger again in domesticated beasts. It's stronger yet in humans than in animals. That's why we have mastery over them. 65

It's stronger in nāgas, gandharvas, yakșas and other divine beings than in humans, sire. 66

In mighty Indra, protector of his subjects, it's stronger than in all the other deities. Brahmā is also set apart by a greater share of energy than mortal men. 67

All these are forms of Viṣnu, sire, since they're pervaded by his energy, as by ether. 68

The second state of the being known as Viṣnu on which practitioners of yoga meditate, great sage, is the shapeless form of the Absolute, called by the wise 'the existent'. 69

All those energies are established in it, sire; it's a form of the universal being and is the other great form of Hari. 70

It brings forth, as if in sport, deities, animals, humans and other living things, all of which are forms of his energy, your majesty. 71

This all-pervading, uninterrupted activity of the immeasurable deity is for the benefit of the worlds and does not arise for the sake of action. 72

One disciplined through yoga should contemplate that form of the universal being, sire, to purify himself, as it expunges all iniquity. 73

Just as fire with leaping flames burns a dried-out thicket when fanned by wind, so does Viṣnu abiding in ascetics' hearts destroy their sins. 74

One should therefore fix one's mind on the basis of all forms of energy, a technique known as pure dhärañă, or 'holding'. 75 
It's the perfect place for one's own mind and for the universal being. It lies beyond the three modes of realisation and is attained by ascetics for their liberation, sire. 76

The minds of others find no refuge, tiger of a man. The deities and all other imperfect beings come into existence as the result of actions. 77

The manifest form of the lord has no desire for any other refuge. This meditation is called 'holding' because the mind retains this very image. 78

Now you'll hear about the form of Hari to contemplate, your majesty. In the absence of such a basis, holding is impossible: 79

A lovely, pleasing face, eyes like lotus petals, smooth cheeks, a broad and brilliant forehead, 80

His well-matched ears with finest earrings hanging from their lobes, a neck as white as conch-shell, while his broad chest bears Śrīvatsa. 81

His belly with its deep navel is crossed by three graceful folds. His long arms are either four or eight in number. 82

His strong legs are well-formed, and his lotus-like feet and hands are shapely. One should meditate on this form of Viṣnu, the Absolute being, clad in garments of pure yellow. 83

Adorned with diadem, lovely armlets, bracelets and other jewellery, 84

Holding bow and conch, mace and sword, prayer beads and discus - the ascetic, who himself consists of Viṣnu, should contemplate this form with a focused mind. 85

As long as he maintains the practice of dhäraña, your majesty, while walking, standing or doing anything he likes, if this image never leaves his heart, he may regard the practice as perfected. 86

Next, the wise person may meditate on the lord in tranquil form, without the conch or sword, bow or discus or other items, holding only prayer beads. 87

When this state of $d \bar{a}$ ran $\bar{a}$ is stable, he should visualise the image without the diadem, armlets and other ornaments. 88

Then the wise man should set his mind on the deity with a single limb. Next he should meditate on the body to which that limb belongs. 89

A single mental image of Viṣnu's form, stable and unbroken, is known as dhyāna, or 'meditation', and is reached in six initial stages, sire. 90 
When this heavenly form is borne in mind, free from other thoughts, as a result of meditation, that state is known as samädbi. 91

If the highest Absolute is to be achieved, your majesty, then knowledge will enable it. Similarly, the Self is reached when all other forms of realisation are exhausted. 92

Consciousness has the means, while knowledge is the means by which one reaches liberation. When liberation has been reached, the role of knowledge has been fulfilled and is no more. 93

When the individual self reaches the realisation of its true nature, then it becomes one with the supreme Absolute, no longer divided from it. The separation of the two is caused by ignorance. 94

When ignorance that gives rise to difference is finally transcended, who would distinguish between the Absolute and the self, when such distinction does not exist? 95

I've described yoga to you, Khāṇdikya, as requested, part in brief and part in full. What else may I do for you? 96

\section{Khäṇ dikya:}

Now that the reality of yoga has been explained, you've done everything for me. All impurities in my mind have been removed through your instruction. 97

The word 'mine', which I've used so often, is a lie. Those who know what must be known can't say otherwise, your majesty. 98

'I' and 'mine' are forms of ignorance that dictate daily conduct. The highest goal can't be described, as it's beyond the scope of words. 99

Go now, for all you've done is for my benefit, Keśidhvaja, as you've described eternal yoga, which leads to liberation. 100

\section{Parāśara:}

King Keśidhvaja received due homage from Khāṇịikya, brahmin, then returned to his own capital. 101

Khāndikya gave his kingdom to his son and retreated to the forest with his heart set on Govinda to perfect his yoga practice. 102

There, delighting in this single quest and purified by virtues such as self-restraint, the king achieved absorption in the purest Absolute in the form that's known as Viṣnu. 103 
Keśidhvaja turned his back on his responsibilities and indulged his senses, but still performed the rituals without attachment to the outcome to accomplish liberation. 104

In spite of worldly pleasures, he was cleansed of all his sins and, being purified, brahmin, achieved that perfection which results in the destruction of all suffering. 105

So ends Chapter Seven in Book Six of the glorious Viṣnu Purāna.

\section{The benefits of listening to the Viṣnu Purāna}

\section{Parāśara:}

I've thus described in full the third and final kind of dissolution: liberation as absorption in the everlasting Absolute. 1

I've told you all about the first and subsequent creations, the lineages of the patriarchs, the periods of the Manus and the deeds of the royal dynasties. 2 This imperishable Vaiṣnava purāna, which sweeps away all sins, is the first among all sacred texts as a path to reach the goals of human life. 3

I've duly related this everlasting scripture to you, Maitreya, as you wished to hear it. What else should I speak about? Ask me now, and I'll respond. 4

\section{Maitreya:}

Master, you've told me all I asked about. I've listened with devotion, sage, and have no further questions. 5

All my doubts have been dispelled and now my mind is clear. Through your kindness, I understand the origin, state and conclusion of the world. 6

I understand Viṣnu's fourfold nature and his threefold energy, guru, and I comprehend completely the threefold nature of realisation. 7

I understand all this as the product of your kindness. What use is further knowledge, brahmin, when the universe and Viṣnu are but one? 8

I've reached my goal and have no further doubts, thanks to your mercy, sage, as now I fully understand the duties of all four orders and other practices. 9 I understand completely the sacrificial and meditative modes of pious life. Be merciful, best of brahmins. I have nothing more to ask. 10

Forgive me for troubling you to relate all this, guru, but the wise make no distinction between a student and a son. 11 


\section{Parāśara:}

This purāna which I've relayed to you is the equal of the Vedas. By hearing it, the sins amassed from faults of every kind will be dispelled. 12

I've told you all about the first and subsequent creations of the world, the lineages, Manvantaras and dynastic histories. 13

I've spoken of the deities, Daityas, gandharvas, nāgas, rākșasas, yakșas, vidyādharas, siddhas and apsarases. 14

I've described the purest sages imbued with ascetic energy, the fourfold social system, men of uncommon feats, 15

Hallowed places on this fertile earth, holy seas and rivers, sacred mountains and the exploits of the wise, 16

Traditions such as those that govern the four communities and all about the schools of Vedic learning. Hearing this, one is freed at once from all misdeeds. 17

I've described Lord Hari, the universal everlasting cause of creation, preservation and destruction of the world, who abides at the heart of everything. 18

By calling his name, even unintentionally, all one's sins are scattered in an instant, like frightened deer fleeing from a lion. 19

When a person speaks his name with faith, he is completely purified, Maitreya, just as fire refines the ores of minerals. 20

The moment Viṣnu is called to mind, the awful faults of the Kali age, which lead folk to infernal grief, are ended. 21

Brahmā, born of the golden egg, Indra king of gods, Rudra, Āditya, the Aśvins, Vāyu, the Fires, the Vasus, the Sādhyas, the Viśvedevas and other gods, 22

The yakșas, rākșasas, nāgas, siddhas, Daityas, gandharvas, Dānavas, apsarases, stars, constellations and all the planets, 23

The Seven Sages, the quarters of the sky and their protectors, brahmins and other mortals, animals of farm and forest, 24

Those that creep and crawl, those that course the sky, paläsa trees and other plants that grow upon the earth, forests, mountains, oceans, rivers, the lower realms and all that underlies them, 25 
Together with sound and other objects of the senses, and the universe entirely in the form of the cosmic egg, brahmin—all this consists of Viṣnu, yet is no more to him than an atom is to Meru, best of brahmins. 26

$\mathrm{He}$ is all and is all-knowing. He takes all forms, and yet is formless. He is the lord who is praised as Viṣnu, destroyer of all worldly sin. 27

The entire reward that's won by a man who has finished his ablutions at the end of an Aśvamedha, best of sages, may be gained by hearing this account. 28

The reward that's won by a man who has fasted at Prayāga, Puṣkara, Kurukșetra or Arbuda may be gained by hearing this. 29

The highly meritorious reward achieved from a well-conducted yearlong Agnihotra sacrifice, brahmin, may be gained at once by hearing this purāna. 30

After bathing in the waters of the Yamunā at Mathurā on the twelfth day of the bright fortnight in the month of Jyesțha, and having beheld Hari, one attains the highest state. 31

But that same reward is gained when one recites this narrative, sagacious brahmin, with perfect concentration and one's mind on Keśava. 32

One who bathes in the Yamunā, best of sages, on the twelfth day of the bright fortnight in Jyeșthāmūla, after fasting, 33

And who has worshipped Acyuta correctly at Mathurā with a focused mind, achieves the full reward of an Aśvamedha sacrifice. 34

Seeing the felicity enjoyed by ancestral spirits who'd been redeemed by their descendants, other spirits uttered this complaint: 35

'If only someone in our family would bathe in the waters of the Yamunā and praise Govinda at Mathurā after fasting, 36

In the bright fortnight of Jyeșthāmūla, we, too, might enjoy such felicity and be redeemed by our descendants.' 37

After worshipping Janārdana in the bright fortnight of Jyeșṭāmula, one born in an upright family may make food offerings of pinda to his ancestors by the Yamunā. 38

After praising Kṛșna with devotion at that time and place, and offering piṇda to his ancestors and bathing in the waters of the Yamunā, 39 
The auspicious reward he receives while redeeming his own forefathers is the same as a devotee receives from hearing just one chapter of this purāna. 40

This is the peerless means of salvation for those who fear samsāra. It dispels all nightmares and sets folk free from all defilements. 41

This sage discourse was related in former times by lotus-born Brahmā to R.bhu. He relayed it to Priyavrata, and Priyavrata to Bhāguri. 42

Bhāguri passed it to Stambhamitra, and he related it to Dadhìca. Dadhīca passed it to Sārasvata, and Bhṛgu heard it from him. 43

Bhṛgu passed it to Purukutsa, and he repeated it to the river Narmadā. Narmadā passed it to the nāgas Dhṛtarāṣṭra and Āpūraṇa. 44

They related it to the nāga king Vāsuki, brahmin, and he passed it to Vatsa, who repeated it to Aśvatara. 45

He passed it on to Kambala, from whom it came to Elāpatra. 46

When the sage Vedaśiras visited the lower realm of Pātāla, he heard this purāna and related it to Pramati. 47

Pramati passed it on to wise Jātūkarṇa, and Jātūkarṇa repeated it for other beings of worthy conduct. 48

With the boon Pulastya granted me, I acquired this sacred text and now I've given it to you, Maitreya. 49

At the end of the Kali age, you'll narrate it to Śinìka. 50

One who hears this-the closely guarded means of removing the stains of Kali-brahmin, will be freed from all misdeeds. 51

One who hears it daily thereby praises all the gods with more effect than may ancestors, yakșas and other mortals. 52

The hard-won merit gained by giving a tawny milk cow to a brahmin is certainly achieved by hearing just ten chapters of this discourse. 53

One who hears this whole purāna with his mind on Acyuta, the universal, all-embracing foundation of all the worlds, the refuge of the Self, who is both knowledge and its object, who has neither start nor finish, the benefactor of all immortals_-such a one will surely win the whole reward of an Aśvamedha sacrifice. 54 
The lord, master of moving and unmoving things, who consists of knowledge of the Absolute, infallible Acyuta, overseer of creation, preservation and destruction of all the world, is present at the beginning, end and middle of this purāna. Those who hear it, read it or hold it in their hearts with faith will win the highest state of purity existing nowhere else in all the worlds: Hari, the singular state of perfection. 55

Those who set their minds on Hari never go to hell, but heaven also makes it hard to contemplate him. When Hari fills a person's heart and mind, even Brahmā's realm will count for little. Since you are the eternal being abiding in people's stainless minds, the bestower of liberation, then is it any wonder that misdeeds are dispelled when you, Acyuta, are praised? 56

Those who understand and offer sacrifices worship Hari as the everlasting lord of sacrifice with the offerings that they make. The knowledgeable contemplate him as consisting of the Absolute, the highest and higher than the highest. Having attained his state, one is no longer subject to birth or death, gain or loss. He is not existent or nonexistent-what more can be said about Hari? 57

In the form of the ancestors, the lord enjoys correctly made oblations. In the form of a deity, he has neither start nor finish and is invoked with cries of svāba and svadhā. In the form of the Absolute, all power abides in him. The measures by which other things are quantified cannot be applied to him. When Hari enters through your ear, he destroys all sins. 58

I bow to the highest spirit, praiseworthy lord, who has neither start nor finish, who is not subject to decay or gain or loss, whose substance is untouched by change. 59

I bow to the everlasting, changeless spirit who assumes all qualities, both one and many, pure but seeming not so, as he appears in different forms, imbued with knowledge and the source of every being's power. 60

I praise him, the single essence of all knowledge, sacrifice and ascetic practice, who skilfully provides enjoyments for individuals, who is at the heart of all three qualities, who is the changeless cause of the cause of existence, the source of every form, who never ages. 61

I always bow to him, who arranges space and air, fire and earth and water, who gifts the sound and other sensations experienced by the senses, who benefits humanity with all his actions and who is manifest, pure and subtle. 62 
THE VIṢNUU PURĀṆA

Thus may Hari, the eternal unborn lord, whose form is manifold and embodies both Spirit and Nature, bestow on all humanity supreme beatitude beyond the reach of birth, decay and other woes. 63

So ends Chapter Eight in Book Six of the glorious Viṣnu Purāna.

End of Book Six.

End of the glorious Viṣnu Purāna. 
This text is taken from The Viṣnu Puranna: Ancient Annals of the God with Lotus Eyes, translated from the Sanskrit by McComas Taylor, published 2021 by ANU Press, The Australian National University, Canberra, Australia.

doi.org/10.22459/VP.2021.06 